огляди

\title{
Plant sulfolipid. II. Mutant study and phosphate deficiency
}

\author{
N. Yu. Taran, A. A. Okanenko, O. I. Kosyk \\ National Taras Shevchenko University \\ 64 Volodymyrska str, Kyiv, Ukraine, 01033 \\ a_okanenko@yahoo.co.uk
}

\begin{abstract}
Study with SQDG-deficient mutants showed that formation of the sulfonic acid precursor, $U D P$-sulfoquinovose, in higher plants is considered to be catalyzed by the orthologous plant proteins $S Q D 1$. The second required plant enzyme, SQD2, is highly similar to glycosyltransferases and it is proposed that this protein represents sulfolipid synthase. The results of recent works have shown that for the stable activity PS II needs the presence of SQDG and that it participates in PS II recovering through some mechanism dependent on light. Under phosphate-limiting conditions a decrease in the content of one acidic lipid (PG) was accompanied by an increase in the content of the other acidic lipid (SQDG), which resulted in the maintenance of a certain level of total acidic lipids of chloroplast membranes.
\end{abstract}

Keywords: glycolipid, sulfolipid, sulfoquinovosyldiacylglycerol, $S Q D G$.

The creation of SQDG (sulfoquinovosyldiacylglycerol)-deficient mutants made it possible to study SQDG function in vivo. However, before analyzing this data it would be useful to present available information about the genes involved in SQDG biosynthesis. Study on genetic apparatus performed mainly on the bacteria revealed four such genes designed as $s q d A, s q d B, s q d C$ and $s q d D$ in Rhodobacter sphaeroides [1]. The predicted $s q d B$ gene product showed sequence similarity to UDP-glucose epimerase from various organisms [2]. Using $R$. sphaeroides mutant with inactivated $s q d D$, Rossak et al. [3] reported the accumulation of a water soluble ${ }^{35} \mathrm{~S}$-labeled compound identified as UDP-sulfoquinovose. Thus, it was supposed that the most possible gene for encoding SQDG synthase at $R$. sphaeroides is $s q d D$, and the protein is similar to glycosyl transferases of glycogenin type. However, the

(c) Інститут молекулярної біології і генетики НАН України, 2009 enzymatic activity was not observed in vitro [4], perhaps, because $R$. sphaeroides $s q d D$ codes only one SQDG synthase subunit whereas for full functional state the auxiliary proteins are necessary. Data obtained with $R$. sphaeroides sqdC null-mutant allowed to suggest that the $s q d C$ gene product mediates the substrate specificity of the sulfoquinovosyl transferase encoded by $s q d D$ and catalyses the final reaction of sulfolipid biosynthesis or ensures the association of the enzyme with membrane.

Another gene $s q d X$ essential for the sulfolipid biosynthesis was revealed in the cyanobacterium Synechococcus sp. strain PCC7942. Inactivation of $s q d X$ resulted in complete sulfolipid deficiency which could be restored by introducing the $s q d X$ genes of either Synechococcus or Synechocystis. Thus, the last reaction of SQDG biosynthesis in cyanobacteria is catalyzed by another glycosyl transferase type than in R. sphaeroides [5]. 
The formation of the sulfonic acid precursor, UDP-sulfoquinovose, in higher plants is considered to be catalyzed by the orthologous plant SQD1 proteins. Like the bacterial $s q d B$ gene products, the SQD1 protein has a sequence similar to the sugar nucleotide modifying enzymes and it was assumed to be involved in the biosynthesis of UDP-sulfoquinovose from UDPglucose $[1,2,3,6]$. The results of the latest work showed that the SQD1 protein of Arabidopsis thaliana is an orthologue of the bacterial SQDB proteins [7] and catalyses the formation of UDP-sulfoquinovose from UDP-glucose and sulfite derived from the APS reductase reaction [8].

The second required plant enzyme, SQD2, is highly similar to glycosyltransferases [9], and it is proposed by $\mathrm{Yu}$ et al. [10] that this protein represents the sulfolipid synthase. The high similarity between the two Arabidopsis proteins SQD1 and SQD2 and the cyanobacterial sulfolipid proteins SqdB and SqdX [5, 6] and their ability to functionally reconstitute sulfolipid biosynthesis in Escherichia coli allowed to conclude that they are true orthologues of SqdB and $\mathrm{SqdX}[10]$.

However, the analyses of mutants revealed that the extent of the requirement for SQDG varies among the photosynthetic organisms. A null-mutant of $R$. sphaeroides completely lacking SQDG obtained by disruption of its $s q d B$ gene showed the same growth rates as wild-type algae under optimal growth conditions $\left(150 \mu \mathrm{mol} \cdot \mathrm{m}^{-2} \cdot \mathrm{s}^{-1}\right)$. The ratios of various components of the photosynthetic electron transport chain, as well as the electron transfer rates during cyclic electron transport were not altered [11]. The SQDG-deficient Synechococcus sp. PCC7942 nullmutant showed also the same growth rates under optimal phototrophic growth conditions as the wild type suggesting that SQDG was not essential for oxygenic photosynthesis [6]. The rates of oxygen evolution as a function of proton flux density curves were nearly identical for the wild type and mutant. The similarity of emission spectra following chlorophyll $a$ excitation at $440 \mathrm{~nm}$ indicated that neither the chlorophyll $a$ binding to the core antenna proteins CP43 and CP47 nor the excitation energy transfer to the $\mathrm{RC}$ was affected. Maintaining a certain level of total anionic lipids in the membranes seems to be crucial for the organism, because reduction in $\mathrm{PG}$ under phosphate limitation in the wild type was compensated by an increased level of SQDG. The SQDG-deficient mutant, however, would be unable to respond in the same way to phosphate limitation. It was concluded that SQDG did not play a specific role in oxygenic photosynthesis but it was suggested that SQDG could act as a substitute for anionic phospholipids under phosphate-limiting growth conditions [6].

On the other hand, a study with the Chlamydomonas mutant SQDG-deficient mutant $h f-2$ showed that it had a decreased growth rate (down $17 \%$ ) probably because of an approximately $22 \%$ decrease in photosynthetic activity. SQDG function is connected according to these authors with supporting PS II activity via association with core, LHC II-A and LHC II-B [12]. Besides, cells of $h f-2$ tended to suffer from photoinhibition, if light intensities higher than $600 \mu \mathrm{mol} \cdot \mathrm{m}^{-2} \mathrm{~s}^{-1}$ were used for $30 \mathrm{~min}$ [13]. PS II activity was $42 \%$ lower in $h f-2$ than in its parent, whereas Chl $a / b$ ratios and the rate of PS I electron transport was relatively unaffected. Light-saturated PS II activity was lower in $h f-2$ which indicated that the activity of the PS II RC was decreased. Therefore, the absence of SQDG reduced the activity of the PS II RC complex with a little effect upon PS I and LHC II. The lowered PS II activity in $h f-2$ could be due to an impairment of the RC in the PS II complex, rather than to a decrease of the antenna size in PS II, or a decrease in the efficiency of energy transfer from LHC II to the RC [12]. Because the spectroscopic properties and stoichiometry of the pigment protein complexes were no different to the wild type, it was proposed that SQDG might play a modulating role rather than being absolutely necessary for the structure of PS II. Lipid analyses showed that SQDG was concentrated in the PS II core complex (13.7 mol\% ) and two types of LHC II (17.8 mol\% in LHC II-A and $23.6 \mathrm{~mol} \%$ in LHC II-B), but not in the PS I complex. Thus, SQDG could contribute to the activity of the PS II RC by association with the PS II core complex while SQDG bound to LHC II may modulate the PS II RC function because the PS II core complex and LHC II are organised into the PS II complex in vivo [12]. But further investigation gave evidence that the $h f-2$ decreased PS II activity can 
be restored by incorporation of exogenous SQDG from the medium. In order to explore which part of SQDG head is more important for PS II functioning two modified SQDGs, methylated-SQDG in which a sulfonic residue of sulfoquinovose was methylated and sugar-oxidized SQDG in which the sugar part of sulfoquinovose was cleaved by a periodate oxidation, were applied. The methylated SQDG did not affect the PS II activity of $h f-2$, whereas the sugar-oxidized SQDG raised it only a little. It was concluded, that the sulfonic residue of SQDG may be more important than the sugar part for the maintenance of the PS II activity, although both may be required for the support of full PS II activity [13]. Specific binding sites could be implicated, as the restoration of the PS II activity is achieved by addition of a very small amount of SQDG to thylakoid membranes. Therefore, a conformational change of the PS II complex may cause the decrease in the PS II activity in $h f-2$ by the lack of specific binding of SQDG to the PSII complex. Alternatively, the change of the lipophilic surrounding at $\mathrm{Q}_{B}$ site of the PS II complex might cause the decrease in the PS II activity even without the conformational change in protein complex. According to the increase in the $h f-2$ sensitivity to diuron, the limitation of the electron transfer at the exit of the PSII complex might lower the whole PS II activity as a result of the change in the lipophilic environment at the $\mathrm{Q}_{\mathrm{B}}$ pocket. The electron flow in PS II might be commonly affected by the negative charge of SQDG and/or PG which are both located in the region of the PS II complex. [14].

Next work of the authors [15] done with $h f-2$ showed that the lowered activity in the mutant was derived from a decrease in the efficiency of the electron donation from water to tyrosine $\mathrm{Z}$, not from the efficiency of the electron transport from $Q_{A}$ to $Q_{B}$. Despite the change in the surroundings of the $Q_{B}$ site, the electron transport from $Q_{A}$ to $Q_{B}$ on the acceptor side of PS II was not altered so that the defect should be on the donor side of PS II. Presumably, the change in the conformation of the PS II complex, particularly D1 polypeptide, influences the properties of the Mn atoms in $h f-2$. As a consequence, the efficiency of the electron donation from $\mathrm{Mn}$ to tyrosine $\mathrm{Z}$ would be decreased. The binding site of $Q_{B}$ and $Z$ is known to locate on the same polypeptide, D1 (PsbA protein) of PS II. The unusual conformational change of D1 polypeptide in $h f-2$ may cause the decrease in the electron donation to $\mathrm{Z}$ as well as the increase in the affinity of DCMU to the $\mathrm{Q}_{\mathrm{B}}$ site. Under high light condition, $h f-2$ was slightly more sensitive to photoinhibition, and the recovery was a little slower than in the wild-type [13]. The D1 polypeptide of the PS II RC seems to be one of the most severely modified subunits in $h f-2$. Thus, it was concluded that SQDG contributes to maintaining the conformation of PS II complexes, particularly that of D1 polypeptides, which are necessary for maximum activities in Chlamydomonas.

The recent results [16], obtained on a mutant of C. reinhardtii defective in SQDG $(h f-2)$ have shown that the physical properties of the PS II complex were altered by the loss of SQDG. The PS II core complex of $h f-2$ disappeared when detergent (dodecyl $\beta$-Dmaltoside) concentration was raised to $2 \%$, because of dissociation of the subunits comprising the complex. Besides, the capacity of the complex to keep its subunits assembled was lowered and sensitivity of the PS II activity to DCMU and CMU was enhanced, as suggested, because of alteration in the structure of the $\mathrm{Q}_{\mathrm{B}}$-binding site rather than in the lipid environment around the site. Incubation of the wild type at $41{ }^{\circ} \mathrm{C}$ in the light, in contrast to in the dark, had little deleterious effect on the PS II activity, but the effect of light was less pronounced for $h f-2$. PS II inactivated to $60 \%$ of the initial level by dark incubation at $41{ }^{\circ} \mathrm{C}$ was reactivated by following illumination even at $41{ }^{\circ} \mathrm{C}$ to more than $90 \%$ in the wild type, but only to $70 \%$ in $h f-2$. These results suggest that for the stable activity PS II needs the presence of SQDG and that it participates in PS II recovering through some mechanism dependent on light.

In other investigation the mutant of Synechocystis $s p$. PCC6803, designated SD1, lacked SQDG synthetic ability and required SQDG supplementation for its growth, was studied [17]. It incorporated exogenously supplemented SQDG not only into the cell but also into the thylakoid membranes, indicating that Synechocystis sp. PCC6803 possesses some mechanisms for lipid incorporation. After transfer from SQDG-supplemented to SQDG-free conditions, SD1 showed decreased the net photosynthetic and PS II activities on a chlorophyll basis but it maintained normal amounts 
of cytochrome $\mathrm{b}_{559}$ and $\mathrm{D} 1$ protein, indicating that the PS II complex content changed little. These results are consistent with the results obtained with $C$. reinhardtii. In contrast, the SQDG null-mutant of Synechococcus $s p$. PCC7942 showed the normal level of PS II activity with little effect on its sensitivity to PS II herbicides. The authors suggest that SQDG would maintain the normal conformation of a region such as the $\mathrm{Q}_{\mathrm{B}}$ binding site of the D1 protein and consider the difference in the SQDG requirement for PS II to be species-specific in cyanobacteria.

As it was said earlier, maintaining a certain level of total anionic lipids in the membranes seemed to be crucial for the organism and phosphate limitation induced lipid composition changes. Phosphorus is an essential element of mineral nutrition that often limits plant growth and development. Under phosphoruslimited conditions plants undergo substantial alterations in membrane structure and there is information demonstrating that phosphorus deficiency changes lipid composition in cyanobacteria and various plant organs [18].

First of all, the data should be mentioned concerning gene expression while phosphate starvation. It is known that about $7 \%$ (44 genes) of Pi responsive genes are involved in the lipid biosynthetic pathways. Induced genes largely represented those coding for enzymes involved in phospholipid degradation and galacto- and sulfolipid synthesis [19]. The genes involved in the subsequent utilization of DAG to synthesize galactolipids (MGDG, DGDG) were strongly up-regulated at early stages of Pi deprivation. There are two enzymes, MGD1 and DGD1, which provide the bulk of galactolipids in the chloroplast and in photosynthetic tissues. Under phosphate-limited growth conditions and in non-photosynthetic tissues MGD2/3 and DGD2 are highly active [20]. The genes coding for MGDG synthases (MGD2 and $M G D 3$ ) were induced 4- to 10-fold during short-term Pi deprivation whereas the expression of $D G D 1$ and $D G D 2$, coding for DGDG synthases, was enhanced during mediumand long-term $\mathrm{Pi}$ deficiency, respectively [19]. Although DGD1 seems to act preferentially on the MGDG molecular species with 18-carbon fatty acids in the two positions of MGDG in vivo, DGD2 seems to act on MGDG with a 16-carbon fatty acid in the $s n-1$ position and an 18-carbon fatty acid in the $s n$-2 position of the DAG moiety [21], a lipid species preferentially formed under the phosphate starvation conditions in Arabidopsis [22]. Similarly, the genes encoding UDPglucose-4-epimerase, which convert UDP-glucose to UDP-galactose (galactolipid precursor), and UDPgalactose-4-epimerase (involved in SQDG biosyntheses) were induced during medium- and long-term Pi deficiency. Comparatively, the genes coding for UDP-sulfoquinovose synthase and UDP-sulfoquinovosyl:DAG sulfoquinovosyl transferase exhibited early and sustained induction during Pi deficiency treatments, this was reflected by a 4-fold increase in the level of SQDG in P-deficient leaves during long-term Pi deficiency [19]. The results presented by Wasaki with coworkers [23] evidence that UDP-galactose4-epimerase is up-regulated while UDP-glucose-4epimerase is down-regulated. It means that equilibrium of UDP-galactose and UDP-glucose is inclined to increase UDP-glucose, which might contribute to supplying the substrate for sulfoquinovose. The genes $S Q D 1$ and $S Q D 2$ encode proteins involved in the biosynthesis of sulfolipids, and their expression increases in P-deficient plants [7, 23-25].

During phosphate starvation the total phospholipid content decreases being substituted by nonphosphorus lipids like glycolipids to support membrane functionality and allowing photosynthesis to continue despite a reduction in phospholipid content. The substitution and recycling of phospholipids during $\mathrm{P}$ deficiency can release Pi from phospholipid head groups thus creating additional sourse of phosphorus $[10,26]$.

The information available declares that a decrease in the amounts of both PG and MGDG, with a concomitant increase in those of DGDG and SQDG takes place. There are many evidences of theses changes. The similar phenomena were observed in photosynthetic bacteria $[6,11], C$. reinhardtii $[27]$ and A. thaliana [7]. In particular, the contents of the chloroplast acidic lipids, SQDG and PG, were reduced in the cells of $C$. reinhardtii with exposure to sulfur- or phosphorus-source limitation, respectively. The decrease in the content of one acidic lipid was accompanied by the increase in the content of the other acidic lipid, which resulted in the maintenance of a 
certain level of total acidic lipids of chloroplast membranes. The contents of these acidic lipids were altered by growth under sulfur- or phosphorus-limiting conditions. The cells grown in medium with a limited sulfur supply showed a loss of SQDG content whereas PG amount increased by 2 -fold in correspondence with the decreased level of SQDG, and therefore the summed content of these two lipids was little affected. Similarly (as it was said earlier) in SQDG-deficient mutants the amount of negatively charged lipids was kept constant by an increase of PG $[4,12,28]$. Cells exposed to a limited phosphorus supply showed a $40 \%$ decrease in the PG content with an increase in the SQDG content, which resulted again in almost constant content of total acidic lipids [27].

SQDG was also important under conditions of phosphate starvation, when a SQDG-deficient mutant of $R$. sphaeroides ceased growth much earlier than the wild type. In the wild type PG was replaced as a boundary lipid by the anionic glycolipid SQDG. Such an adaptation was not possible for the SQDG-deficient mutants [4].

The pgs $A$ mutant (defective for the biosynthesis of PG) of the cyanobacterium Synechocystis sp. PCC6803 showed the significant increase in SQDG content comparing to the wild type in PS II particles whereas in thylakoids this lipid amount did not changed. Authors considered the functional importance of SQDG operating to be quite different from that of PG because of the difference between the sulfoquinovose and phosphate groups. Nevertheless they suggest that because SQDG and PG molecules are negatively charged at neutral $\mathrm{pH}$, it is possible that they interact with components in protein-cofactor supercomplexes in thylakoid membranes and would thus support important structural roles in those complexes [29].

Besides, a mutant defective in the CDP-diacylglycerol synthase gene constructed from a cyanobacterium Synechocystis sp. PCC6803 required PG supplementation for growth but has constant SQDG level, despite incorporation of various amounts of exogenously supplemented PG or after a decrease in the PG content after the shift to PG-free medium [30]. Experiments with the mutant Synechocystis (defective in $c d s A$ or $p g s A$ genes) showed that PG was essential for cell growth and was needed for maintenance of the chlorophyll-protein complex levels and normal conformation and activity of the PS II complex [27]. SQDG was also discovered in the non-photosynthetic, root nodule-forming bacterium Sinorhizobium meliloti. However, a SQDG-deficient mutant of $S$. meliloti disrupted in $s q d B$ was capable of inducing functional nodules and did not show any obvious impairment of function under different conditions. Thus, no specific role can be assigned to bacterial SQDG, in either nodule-associated or free-living cells [31].

Investigation carried out with Arabidopsis thaliana grown on medium with reduced amounts of phosphate, as well as in the pho mutant of $A$. thaliana deficient in phosphate transport has shown, that amount of SQD1 mRNA and SQD1 protein in the phol mutant and in the wild type grown on decreasing amounts of phosphate was drastically increased. Irrespective of the light conditions, the sum of SQDG and PG remained nearly unchanged in the phol mutant as compared to the wild-type suggesting that the total amount of negatively-charged lipids was important. Despite alterations in their ultrastructure, mutant thylakoids showed virtually no changes in photosynthetic electron transfer, $\mathrm{O}_{2}$ evolution and excitation energy allocation to the RCs. It was assumed that PG deficiency can, at least partially, be compensated for by another anionic lipid, in this case SQDG [32]. It was revealed a 15-fold increase in the amount of $S Q D 1$ mRNA in the wild type grown in the presence of $0.01 \mathrm{mM}$ phosphate compared with that grown in the presence of $1 \mathrm{mM}$ phosphate. The increase in the relative amounts of SQDG appears to be proportional to the SQD1 mRNA and SQD1 protein. These results provide strong evidence that a decrease in the internal phosphate concentration, regardless whether imposed by a specific mutation in phosphate transport in the phol mutant or by limiting the external supply of phosphate to the wild type, leads to an increase in the expression of $S Q D 1$ in response to altered availability of inorganic phosphate [7].

So, the $A$. thaliana wild type grown on medium with reduced inorganic phosphate shows an increase in the relative amounts of nonphosphorous SQDG and DGDG with a decrease in phospholipid content. The relative amounts of the two anionic lipids PG and SQDG show an inverse relationship as a function of the phosphate concentration in the medium. 
It was found also that the content of MGDG, the precursor of DGDG and the most abundant galactolipid in plants, remained remarkably constant in the $d g d l$, dgdl/phol and phol A. thaliana mutants. In phol quantity of all phospholipids were found to be reduced, whereas the relative amount of SQDG was increased (1.2 $\mathrm{mol} \%$ in the wild type to $7.4 \mathrm{~mol} \%$ in phol) [22]. The results of another work also evidence that expression of $S Q D 1$ responded specifically to $\mathrm{P}$ starvation and was increased $100 \mathrm{~h}$ after withdrawing $P$. Leaves of Arabidopsis showed increased SQD1 activity after $\mathrm{P}$ withdrawal, which was detectable before P starvation limited growth [26]. Based on this observation it was concluded that the increase in the relative amount of SQDG in response to phosphate deprivation is at least in part the result of an active regulation of the transcription of a gene involved in sulfolipid biosynthesis. It was suggested also that anionic SQDG substitutes for the anionic PG among other adjustments to maintain the proper function of the thylakoid membranes [7].

The results of another work [33] showed that in Arabidopsis leaves major changes at phosphate deprivation included a decrease in phospholipids and a concomitant accumulation of the galactolipid DGDG, thereat UDP-galactose, but not MGDG, serves as the galactose donor for DGDG synthesis catalyzed by DGD2, providing clear evidence for the existence of a UDP-galactose-dependent DGDG synthase in higher plants. The other experiment data showed a remarkable increase in DGDG content from 0.6 to $14.9 \mathrm{~mol} \%$ and SQDG amount from 0.5 to $6.6 \mathrm{~mol} \%$ observed in the roots of Arabidopsis seedlings grown under phosphate deprivation conditions. In contrast, relative amounts of $\mathrm{PC}$ and PE decreased from 33.8 to $21.8 \mathrm{~mol} \%$ and from 51.9 to $21.9 \%$, respectively. These results suggest the existence of metabolic pathways that are activated under phosphorus starvation in Arabidopsis roots to recycle phosphorus from phospholipids (PC and $\mathrm{PE}$ ) and to replace them with DGDG and SQDG [34].

There was also shown that alteration of the lipid content became apparent within 2 days, whereby a decrease of $\mathrm{PG}$ and $\mathrm{PC}$ was compensated by an increase of SQDG and DGDG because phospholipid content is highly reduced but PC and DGDG adopt similar bilayer conformation in the membranes [35]. In leaves of plants grown in Pi-deficient medium, reduction in the levels of all phospholipids except DPG was observed while in the roots no significant difference was detected in any of the phospholipid species, but there was a substantial increase in the level of DGDG. This finding suggests that lipid composition is more sensitive to Pi deficiency in leaves than in roots. Despite an early induction of MGD2 and MGD3, there was no significant increase in MGDG level, even during long-term Pi deficiency that may be due to rapid conversion of MGDG into DGDG by DGD1 and DGD2, whose activity increased during long-term Pi deficiency. Furthermore, the genes DGD1 and DGD2 exhibited differential regulation in roots and leaves - it was shown the preferential biogenesis of DGD2 and DGD1 outside of plastids and in the chloroplast membrane, respectively $[20,35]$. Unlike the phosphate-deprived $d g d 1$ mutant [22], the $d g d 2$ mutant is unable to produce a phosphate stress-induced DGDG molecular species, suggesting that DGD2 is responsible for the biosynthesis of this phosphate stress-specific DGDG pool $[19,21]$. Taken together, the data suggest that MGD2/3 and DGD2 are of conditional importance when the plants experience phosphate stress leading to the biosynthesis of a new DGDG pool, which is distributed from the plastid outer envelope to extraplastidic membranes. This MGD2/3DGD2 pathway may also be affected by other environmental factors depending on the plant species [20].

Most recent study has been performed with a newly constructed SQDG and PG-deficient double mutant sqd2 pgp 1-1 carries a T-DNA insertion in the structural gene for SQDG synthase (SQD2) and a point mutation in the structural gene for PG phosphate synthase $(P G P 1)$. In the mutant, the fraction of total anionic lipids is reduced by approximately one-third, resulting in leaves with reduced chlorophyll content. Photoautotrophic growth of the double mutant is severely compromised, and photosynthetic electron transfer at the level of PS II is affected. The mutant shows altered leaf structure, a reduced number of mesophyll cells, and ultra structural changes of the chloroplasts. The authors consider data obtained to support the conclusion that the total content of anionic thylakoid lipids is limiting for chloroplast structure and 
function, and the total amount of the anionic lipids PG and SQDG is most critical. These findings also support the general concept of substituting one anionic lipid for another under phosphate-limited conditions [24]. The investigation of wheat plants grown in phosphatedeficient and phosphate-sufficient conditions showed that phosphate induced a gradual decrease in PG and MGDG and a concomitant increase in DGDG and SQDG from the first leaf to the second and the third leaf on 16-day-old plants. It is suggested that the alternation in lipid composition in wheat leaves induced by phosphate-deficiency is related to both lipid biosynthesis and PG degradation. PG decrease in younger leaves is mainly due to insufficient phosphate supply for PG biosynthesis, while PG degradation took place in older leaves. The authors consider compounds containing phosphate, such as PA and PC to be involved in the biosynthesis of MGDG and SQDG, thereat the last is the final product of photosynthetic lipid biosynthesis, whilst some molecules of MGDG are used to synthesize DGDG. Therefore, if phosphate is only a limiting factor for MGDG synthesis but not for DGDG synthesis from MGDG, as a result, MGDG should decrease whilst DGDG increase [36].

But some investigators found only phospholipid and galactolipid changes in conditions of phosphorus deficit. For example, study of Arabidopsis polar glycerolipids in response to phosphorus starvation showed that the magnitude of alteration in lipid concentrations was more drastic in roots than in rosettes. Decreases in phosphorus-starved rosettes for PC, PE, and PG were 17, 30, and $28 \%$, respectively, whereas the same lipids in phosphorus-starved roots decreased 51, 65, and $49 \%$, respectively. Moreover, DGDG increased 10-fold in phosphorus-starved roots, but only $72 \%$ in rosettes. Roots respond to phosphorus starvation differently from rosettes not only in terms of growth but also in terms of lipid alterations. In phosphorus starved roots, the concentration of total phospholipids, decreased $35 \mathrm{nmol} / \mathrm{mg}$ dry weights, while the concentration of total galactolipids, including MGDG and DGDG, only increased $8 \mathrm{nmol} / \mathrm{mg}$ dry weights. The authors conclude, that in roots, galactolipids do not quantitatively replace phospholipids as they do in rosettes during phosphorus starvation [37].
The other results evidence that phospholipids are replaced with DGDG, glucosyl ceramides and sterol glycosides in both the plasma membrane and the tonoplast in oat roots at the absence of external phosphate. In plasma membranes a phospholipase D-type activity and a phosphatidic acid phosphatase were the dominant lipase activities induced by phosphate deficiency [38]. The investigators believe these results to index different lipase responses to phosphate limitation in different plant species, different tissues (roots, leaves), and different stages of phosphate limitation stress.

Nevertheless, analyzing the information presented one could conclude that balance between anionic and non-anionic lipids mainly takes place in conditions of phosphorus (or sulfur) limitation.

Thus, the formation of the sulfonic acid precursor, UDP-sulfoquinovose, in higher plants is considered to be catalyzed by the orthologous plant SQD1 proteins. The second required plant enzyme, SQD2, is highly similar to glycosyltransferases and it is proposed that this protein represents the sulfolipid synthase. Mutant studies revealed SQDG function to be connected with supporting the PS II activity by associating with core and LHC II-A and LHC II-B. Sulfonic residue of SQDG is found to be more important than the sugar part for the maintenance of PSII activity, although both may be required for the support of the full PS II activity. Besides, cells of $h f-2$ tended to suffer from photoinhibition and the lowered activity in the mutant was derived from a decrease in the efficiency of the electron donation from water to tyrosine $\mathrm{Z}$, not from the efficiency of the electron transport from $\mathrm{Q}_{\mathrm{A}}$ to $\mathrm{Q}_{\mathrm{B}}$. But the SQDG null-mutant of Synechococcus $s p$. PCC7942 showed the normal level of PS II activity that allowed to consider the difference in the SQDG requirement for PS II to be species-specific in cyanobacteria.

Under phosphate-limiting conditions a decrease in the content of one acidic lipid was accompanied by an increase in the content of the other acidic lipid, which resulted in the maintenance of a certain level of total acidic lipids of chloroplast membranes. PG and SQDG can substitute for each other allowing the organisms to survive stress conditions under which the PG or SQDG biosynthesis is impaired. The biosynthesis of SQDG is 
up-regulated to compensate for the loss of PG so that the anionic character of the thylakoid membranes is preserved [39].

\section{Н. Ю. Таран, О. А. Оканенко, О. І. Косик}

Рослинний сульфоліпід. II. Досліди з мутантами та вплив фосфорного дефіциту

Резюме

Вивчення дефіцитних за сульфохіновозилдіацилгліцеролом (СХДГ) мутантів показало, що утворення попередника сульфонової кислоти UDP-сульфохіновози у вищих рослин каталізує рослинний білок SQD1. Другий необхідний рослинний фермент, SQD2, має велику подібність до глікозилтрансфераз. Вважають, що иеей білок і є сульфоліпідсинтетазою. Встановлено також, що для стійкої активності ФС ІІ необхідна присутність СХДГ, який бере участь у репараиії ФС II через світлозалежний механізм. За умов фосфорного голодування зниження вмісту аніонного фосфатидилглічеролу супроводжується зростанням кількості сульфоліпідів, що таким чином підтримує відносно стійкий рівень вмісту кислих ліпідів у мембранах хлоропластів.

Ключові слова: гліколіпід, сульфоліпід, сульфохіновозилдіацилглічерол.

\section{Н. Ю. Таран, А. А. Оканенко, О. И. Косик}

Растительный сульфолипид. II. Опыты с мутантами и влияние фосфорного дефицита

Резюме

Изучение дефицитних по сульфохиновозилдиацилглищеролу (СХДГ) мутантов показало, что образование предчественника сульфоновой кислоты UDP-сульфохиновозы у высших растений катализирует растительный белок SQD1. Второй необходимый растительный фермент, SQD2, имеет большое сходство с гликозилтрансферазами. Считают, что этот белок и является сульфолипидсинтетазой. Установлено также, что для устойчивой активности ФС II необходимо присутствие СХДГ, который принимает участие в репарациии ФС II через светозависимый механизм. В условиях фосфорного голодания снижение содержания анионного фосфатидилглицерола сопровождается увеличением количества сульфохиновозилдиачилгличерола, за счет чего поддерживается относительно устойчивый уровень содержания кислых липидов в мембранах хлоропластов.

Ключевые слова: гликолипид, сульфолипид, сульфохиновозилдиацилглицерол.

\section{REFERENCES}

1. Benning C., Somerville $C$. R. Isolation and genetic complementation of a sulfolipid-deficient mutant of Rhodobacter sphaeroides // J. Bacteriol.-1992.-174, N 7.-P. 2352-2360.

2. Benning C., Somerville C. R. Identification of an operon involved in sulfolipid biosynthesis in Rhodobacter sphaeroides // J. Bacteriol.-1992.-174, N 20.-P. 6479-6487.
3. Rossak M., Tietje C., Heinz E., Benning C. Accumulation of UDP-sulphoquinovose in a sulfolipid-deficient mutant of Rhodobacter sphaeroides // J. Biol. Chem.-1995.-270, N 43.-P. 25792-25797.

4. Benning $C$. Membrane lipids in anoxygenic photosynthetic bacteria // Lipids in photosynthesis: structure, function and genetics / Eds P.-A. Siegenthaler, N. Murata.-Amsterdam: Kluwer Acad. Publ., 1998.-P. 83-101.

5. Guler S., Essigmann B., Benning C. A cyanobacterial gene, $s q d \mathrm{x}$, required for biosynthesis of the sulfolipid sulfoquinovosyldiacylglycerol // J. Bacteriol.-2000.-182, N 2.-P. 543545.

6. Guler S., Seeliger A., Hartel H., Renger G., Benning C. A null mutant of Synechococcus sp. PCC7942 deficient in the sulfolipid sulfoquinovosyl diacylglycerol // J. Biol. Chem.1996.-271, N 13.-P. 7501-7507.

7. Essigmann B., Guler S., Narang R. A., Linke D., Benning C. Phosphate availability affects the thylakoid lipid composition and the expression of SQD1, a gene required for sulfolipid biosynthesis in Arabidopsis thaliana // Proc. Nat. Acad. Sci. USA.-1998.-95, N 4.-P. 1950-1955.

8. Sanda S., Leustek T., Theisen M. J., Garavito R. M., Benning $C$. Recombinant Arabidopsis SQD1 converts UDP-glucose and sulfite to the sulfolipid head group precursor UDPsulfoquinovose in vitro // J. Biol. Chem.-2001.-276, N 6.P. 3941-3946.

9. Berg S., Edman M., Li L., Wikstrom M., Wieslander A. Sequence properties of the 1,2-diacylglycerol 3-glucosyltransferase from Acholeplasma laidlawii membranes // J. Biol. Chem.-2001.-276, N 25.-P. 22056-22063.

10. Yи B., Xu C., Benning $C$. Arabidopsis disrupted in SQD2 encoding sulfolipid synthase is impaired in phosphate-limited growth // Proc. Nat. Acad. Sci. USA.-2002.-99, N 8.P. 5732-5737.

11. Benning C., Beatty J. T., Prince R. C., Somerville C. R. The sulfolipid sulfoquinovosyldiacylglycerol is not required for photosynthetic electron transport in Rhodobacter sphaeroides but enhances growth under phosphate limitation // Proc. Nat. Acad. Sci. USA.-1993.-90, N 4.-P. 1561-1565.

12. Sato N., Somoke K., Tsuzsuki M., Kawaguchi A. Impared PS II in a mutant of Chlamydomonas reinhardtii defective in sulfoquinovosyldiacylglycerol // Eur. J. Biol. Chem.-1995.234, N 1.-P. 16-23.

13. Minoda A., Sonoike K., Nozaki H., Okada K., Sato N., Tsuzuki $M$. Contribution of SQDG in photosystem II of Chlamydomonas reinhardtii. PS2001// Proc. $12^{\text {th }}$ Int. Cong. Photosynthesis.-Brisbane, 2001.-S5-039.

14. Minoda A., Sato N., Nozaki H., Okada K., Takahashi H., Sonoike K., Tsuzuki M. Role of sulfoquinovosyl diacylglycerol for the maintenance of photosystem II in Chlamydomonas reinhardtii // Eur. J. Biochem.-2002.-269, N 9.-P. 23532358.

15. Minoda A., Sonoike K., Okada K., Sato N., Tsuzuki M. Decrease in the efficiency of the electron donation to tyrosine $\mathrm{Z}$ of photosystem II in an SQDG-deficient mutant of Chlamydomonas // FEBS Lett.-2003.-553, N 1.-P. 109-112.

16. Sato N., Aoki M., Maru Y., Sonoike K., Minoda A., Tsuzuki M. Involvement of sulfoquinovosyl diacylglycerol in the structural integrity and heat-tolerance of photosystem II // Planta.2003.-217, N 2.-P. 245-251.

17. Aoki M., Sato N., Meguro A., Tsuzuki M. Differing involvement of sulfoquinovosyl diacylglycerol in photosystem II in 
two species of unicellular cyanobacteria // Eur. J. Biochem.2004.-271, N 4.-P. 685-693.

18. Raghothama K.G. Phosphate acquisition // Ann. Rev. Plant Physiol. Plant Mol. Biol.-1999.-50.-P. 665-693.

19. Misson J., Raghothama K. G., Jain A., Jouhet J., Block M. A., Bligny R., Ortet Ph., Creff A., Somerville S., Rolland N., Doumas P., Nacry Ph., Herrerra-Estrella L., Nussaume L., Thibaud M.-Chr. A genome-wide transcriptional analysis using Arabidopsis thaliana Affymetrix gene chips determined plant responses to phosphate deprivation // Proc. Nat. Acad. Sci. USA.-- 2005.-102, N 33.-P.11934-11939.

20. Benning C., Ohta $H$. Three enzyme systems for galactoglycerolipid biosynthesis are coordinately regulated in plants // J. Biol. Chem.-2005.-280, N 4.-P. 2397-2400.

21. Kelly A. A., Froehlich J. E., Dormann P. Disruption of the two digalactosyldiacylglycerolsynthase genes $D G D 1$ and $D G D 2$ in Arabidopsis reveals the existence of an additional enzyme of galactolipid synthesis // Plant Cell.-2003.-15, N 11.-P. 2694-2706.

22. Hartel H., Dormann P., Benning C. DGD1-independent biosynthesis of extraplastidic galactolipids after phosphate deprivation in Arabidopsis // Proc. Nat. Acad. Sci. USA.2000.-97, N 19.-P. 10649-10654.

23. Wasaki J., Yonetani R., Kuroda S., Shinano T., Yazaki J., Fujii F., Shimbo K., Yamamoto K., Sakata K., Sasaki T., Kishimoto N., Kikuchi S., Yamagishi M., Osaki M. Transcriptomic analysis of metabolic changes by phosphorus stress in rice plant roots // Plant Cell Environ.-2003.-26, N 9.-P. 1515-1523.

24. Yu B., Benning $C$. Anionic lipids are required for chloroplast structure and function in Arabidopsis // Plant J.-2003.-36, N 6.-P. 762-770.

25. Hammond J. P., Bennett M. J., Bowen H. C., Broadley M. R., Eastwood D. C., May S. T., Rahn C., Swarup R., Woolaway $K$. E., White P. J. Changes in gene expression in Arabidopsis shoots during phosphate starvation and the potential for developing smart plants // Plant Physiol.-2003.-132, N 2.P. 578-596.

26. Andersson M. X., Stridh M. H., Larsson K. E., Liljenberg C., Sandelius A. E. Phosphate-deficient oat replaces a major portion of the plasma membrane phospholipids with the galactolipid digalactosyldiacylglycerol // FEBS Lett.-2003.537, N 1.-P. 128-132.

27. Sato N., Hagio M., Wada H., Tsuzuki M. Environmental effects on acidic lipids of thylakoid membranes // Biochem. Soc. Trans.-2000.-28, N 6.-P. 912-914.

28. Selstam E. Development of thylakoid membranes with respect to lipids // Lipids in photosynthesis: structure, function and genetics. Advances in photosynthesis $6 /$ Eds P.-A. Siegenthaler, N. Murata.-Amsterdam: Kluwer Acad. Publ., 1998.-P. 209-224

29. Sakurai I., Mizusawa N., Ohashi S., Kobayashi M., Wada H. Effects of the lack of phosphatidylglycerol on the donor side of photosystem II // Plant Physiol.-2007.-144, N 3.-P. $1336-$ 1346.

30. Hagio M., Gombos Z., Varkonyi Z., Masamoto K., Sato N., Tsuzuki M., Wada $H$. Direct evidence for requirement of phosphatidylglycerol in photosystem II of photosynthesis // Plant Physiol.-2000.-124, N 2.-P. 795-804.

31. Weissenmayer B., Geiger O., Benning C. Disruption of a gene essential for sulfoquinovosyldiacylglycerol biosynthesis in Sinorhizobium meliloti has no detectable effect on root nodule symbiosis // Mol. Plant-Microbe Interact.-2000.-13, N 6.-P. 666-672.

32. Hartel H., Essigmann B., Lokstein H., Hoffmann-Benning S., Peters-Kottig M., Benning C. The phospholipid-deficient phol mutant of Arabidopsis thaliana is affected in the organization, but not in the light acclimation, of the thylakoid membrane // Biochim. et Biophys. Acta.-1998.-1415, N 1.P. 205-218.

33. Kelly A., Dormann P. DGD2, an Arabidopsis gene encoding a UDP-galactose-dependent digalactosyldiacylglycerol synthase is expressed during growth under phosphate-limiting conditions // J. Biol. Chem.-2002.-277, N 2.-P. 1166-1173.

34. Cruz-Ramirez A., Oropeza-Aburto A., Razo-Hernandez F., Ramirez-Chavez E., Herrera-Estrella L. Phospholipase DZ2 plays an important role in extraplastidic galactolipid biosynthesis and phosphate recycling in Arabidopsis roots // Proc. Nat. Acad. Sci. USA.-2006.-103, N 17.-P. 6765-6770.

35. Jouhet J., Marechal E., Baldan B., Bligny R., Joyard J., Block $M$. A. Phosphate deprivation induces transfer of DGDG galactolipid from chloroplast to mitochondria // J. Cell Biol.2004.-167, N 5.-P. 863-874.

36. Yang W., Feng F.-Y., Hou H.-T., Jiang G.-Z., Xu Y.-N., Kuang T.-Y. Alternation in lipid composition of wheat leaves induced by phosphate deficiency is related to both lipid biosynthesis and phosphatidylglycerol degradation // Acta Bot. Sin.-2004.-46, N 2.-P. 211-215.

37. Li M., Welti R., Wang $X$. Quantitative profiling of Arabidopsis polar glycerolipids in response to phosphorus starvation. Roles of phospholipases Dz1 and Dz2 in phosphatidylcholine hydrolysis and digalactosyldiacylglycerol accumulation in phosphorus-starved plants // Plant Physiol.-2006.-142, N 2.- P. 750-761.

38. Andersson M. X., Larsson K. E., Tjellstrum H., Liljenberg C., Sandelius A. S. Phosphate-limited oat. The plasma membrane and the tonoplast as major targets for phospholipid-toglycolipid replacement and stimulation of phospholipases in the plasma membrane // J. Biol. Chem. 2005.-280, N 30.P. 27578-27586.

39. Frentzen $M$. Phosphatidylglycerol and sulfoquinovosyldiacylglycerol: anionic membrane lipids and phosphate regulation // Curr. Opin. Plant Biol.-2004.-7, N ( ).-P. 270-276.

УДК 755.121

Надійшла до редакції 15.12.07 